\title{
CDK3 wt Allele
}

National Cancer Institute

\section{Source}

National Cancer Institute. CDK3 wt Allele. NCI Thesaurus. Code C49455.

Human CDK3 wild-type allele is located within 17q22-qter and is approximately $27 \mathrm{~kb}$ in length. This allele, which encodes cyclin-dependent kinase 3 protein, plays a role in cell cycle control and cell growth suppression. This allele is located in a chromosomal region that is frequently altered in cancers. 